Taxonomy and systematics

\title{
Morphometric and meristic characterization of the endemic Desert chub Gila eremica (Teleostei: Cyprinidae), and its related congeners in Sonora, Mexico
}

\author{
Caracterización morfométrica y merística de la carpa del desierto endémica Gila eremica \\ (Teleostei: Cyprinidae) y sus congéneres relacionados en Sonora, México \\ Carlos A. Ballesteros-Córdova ${ }^{\mathrm{a}}$, Gorgonio Ruiz-Campos ${ }^{\mathrm{b}}$, Lloyd T. Findley ${ }^{\mathrm{c}}$, \\ José M. Grijalva-Chon ${ }^{\text {a }}$, Luis E. Gutiérrez-Millán ${ }^{a}$, Alejandro Varela-Romero ${ }^{\text {a,* }}$ \\ ${ }^{a}$ Departamento de Investigaciones Científicas y Tecnológicas, Universidad de Sonora, Luis Donaldo Colosio s/n, entre Sahuaripa y Reforma, Col. Centro, \\ 83000 Hermosillo, Sonora, Mexico \\ ${ }^{\mathrm{b}}$ Facultad de Ciencias, Universidad Autónoma de Baja California, P.O. Box 233, 22800 Ensenada, Baja California, Mexico \\ ${ }^{c}$ Centro de Investigación en Alimentación y Desarrollo, A.C./Unidad Guaymas, Carretera al Varadero Nacional km 6.6, Col. Las Playitas, \\ 85480 Guaymas, Sonora, Mexico \\ Received 29 July 2015; accepted 24 November 2015 \\ Available online 16 May 2016
}

\begin{abstract}
The Desert chub, Gila eremica DeMarais, 1991 is a freshwater fish endemic to Northwest Mexico, being described from the Sonora, Matape and Yaqui River basins in Sonora, Mexico. The recent discovery of 2 isolated small populations from the known distribution for this taxon makes necessary an evaluation to determine their specific taxonomical identities (herein designated as G. cf. eremica). Thirty-three morphometric and 6 meristic characters were evaluated in 219 specimens of several populations of the genus Gila in Sonora, including all the known populations of G. eremica. Morphometric measures based on box-truss protocol were standardized by regression models, and analyzed by means of a discriminant function analysis (DFA). The canonical variables 1 and 2 explained 72.4\% of the total variation among analyzed populations. Tree diagram based on squared Mahalanobis distances, as well as scatterplots of centroids, showed G. cf. eremica to be morphologically divergent with respect to known populations of $G$. eremica as well as the other species analyzed. Box plots indicated a slimmer body and a smaller number of pectoral fin rays, and a higher number of lateral line scales as the most distinguishable characters in G. cf. eremica with respect to nominal G. eremica.

All Rights Reserved (C) 2016 Universidad Nacional Autónoma de México, Instituto de Biología. This is an open access item distributed under the Creative Commons CC License BY-NC-ND 4.0.
\end{abstract}

Keywords: Gila cf. eremica; Cyprinidae; New populations; Discriminant function analysis; Northwest Mexico

\section{Resumen}

La carpa del desierto, Gila eremica DeMarais, 1991, es un pez dulceacuícola endémico del noroeste de México, descrito para las cuencas de los ríos Sonora, Mátape y Yaqui en Sonora, México. El descubrimiento de 2 pequeñas poblaciones aisladas del resto de la distribución conocida para este taxón, hace necesaria una evaluación para determinar su identidad específica (designado aquí como G. cf. eremica). Se evaluaron 33 caracteres morfológicos y 6 merísticos en 219 especímenes del género Gila en Sonora, incluyendo todas las poblaciones conocidas de G. eremica. Se estandarizaron las mediciones morfométricas del protocolo de box-truss mediante modelos de regresión y se analizaron por análisis de función discriminante. Las variables canónicas 1 y 2 explicaron el $72.36 \%$ de la variación entre las poblaciones. El árbol de distancias cuadráticas de

\footnotetext{
* Corresponding author.

E-mail address: avarela@guayacan.uson.mx (A. Varela-Romero).

Peer Review under the responsibility of Universidad Nacional Autónoma de México.
} 
Mahalanobis y el gráfico de dispersión de los centroides mostraron morfológicamente divergente a $G$. cf. eremica respecto a las poblaciones conocidas de G. eremica y otras especies analizadas. Los diagramas de cajas indicaron un cuerpo más delgado, menos radios en la aleta pectoral y un mayor número de escamas en la línea lateral como los caracteres más distinguibles entre G. cf. eremica, respecto a la G. eremica nominal. Derechos Reservados (C) 2016 Universidad Nacional Autónoma de México, Instituto de Biología. Este es un artículo de acceso abierto distribuido bajo los términos de la Licencia Creative Commons CC BY-NC-ND 4.0.

Palabras clave: Gila cf. eremica; Cyprinidae; Nuevas poblaciones; Análisis de función discriminante; Noroeste de México

\section{Introduction}

The Desert chub, Gila eremica DeMarais, 1991, is an endemic species in Sonora State in Northwest Mexico (Miller, Minckley, \& Norris, 2005). It has been collected in the Sonora and Matape river basins, with a couple records from the Moctezuma River in the upper Yaqui River basin (Branson, McCoy, \& Sisk, 1960; DeMarais, 1991). Historically, due to its similar morphology and distribution, it was confused with its close relative, Yaqui chub, Gila purpurea (Girard, 1856), originally described from San Bernardino Creek of the uppermost Bavispe River sub-basin of the Yaqui River system in Arizona, and later found farther southward in the Sonora and Matape river basins in Sonora (Barbour \& Miller, 1978; Miller, 1959). However, Hendrickson, Miller, Siebert, and Minckley (1981) detected morphologic differences among populations of G. purpurea from the Yaqui River as compared to nominal populations from the Sonora and Matape river basins. As a result, DeMarais (1991), in an analysis using 26 morphometric and 6 meristic characters, described G. eremica from the latter 2 river basins, and from a single locality in the Moctezuma-Nacozari River sub-basin of the Yaqui system. Differences between G. erem$i c a$ and G. purpurea detected by DeMarais (1991) included, for the former, a larger mouth, shorter distance between origins of pectoral and pelvic fins, and thinner caudal peduncle, but no significant meristic differences. The analysis also detected morphometric and meristic differences compared to Sonora Chub, Gila ditaenia Miller, 1945 (shorter caudal peduncle, longer postorbital mean lengths, and an average of 57 vs. 68 lateral line scales for G. eremica).

The genus Gila is a morphologically heterogeneous and widespread group of fishes inhabiting drainage systems in the Western USA and Northwest Mexico. Studies on the genus Gila suggest that species occurring in USA are mostly sympatric, with a probable hybrid origin for some taxa (DeMarais, Dowling, Douglas, Minckley, \& Marsh, 1992; Dowling \& DeMarais, 1993; Gerber, Tibbets, \& Dowling, 2001; Schönhuth et al., 2014), whereas species of Gila in Mexico might show mainly allopatric distributions, suggesting speciation via peripheral isolation or via predictions of Model III allopatric speciation (Schönhuth et al., 2014; Wiley, 1981). Recent analyses of cyprinids in North America postulate a so-called Revised Western Clade (RWC) (Schönhuth, Shiozawa, Dowling, \& Mayden, 2012), a Creek Chub/Plagopterin Clade (CC/Plagopterin Clade) (Simons \& Mayden, 1997; Simons, Berendzen, \& Mayden, 2003), and an Open Posterior Myodome Clade (OPM) (Bufalino
\& Mayden, 2010a, 2010b, 2010c) as the 3 major clades for the classification of North American cyprinid genera (Schönhuth et al., 2012). The RWC includes the genus Gila along with 10 other genera, and suggests that Gila represents an evolutionary lineage comprised of 19 species, plus the monotypic genera Acrocheilus and Moapa, and the Colorado pikeminnow, Ptychocheilus lucius. However, because molecular analyses do not always recover blue chub, $G$. coerulea, or P. lucius within the proposed Gila lineage, its composition seems arbitrary regarding phylogenetic affinities of these 2 taxa (Schönhuth et al., 2014). Molecular phylogenetic analyses of all known Gila species shows G. eremica, G. purpurea, G. ditaenia, and Mexican roundtail chub, G. minacae from populations in Sonora, to be reciprocally monophyletic (Schönhuth et al., 2014), and places G. eremica in very close relationship to G. purpurea (Schönhuth et al., 2012, 2014), as proposed by DeMarais (1991) based on morphological analysis.

Varela-Romero (2001) firstly reported 2 new populations of G. (cf.) eremica in large spring-fed pools (tinajas) in 2 subtropical canyons of the Arroyo ("creek") El Tigre sub-basin, which intermittently drains the Sierra El Aguaje in the Matape River basin, near San Carlos-Guaymas region, Sonora. These new populations are distantly isolated from other populations in the Sonora and Matape river basins (Fig. 1). The taxonomic identities of these 2 new populations are herein evaluated against other known populations of G. eremica and other selected species of Gila.

\section{Materials and methods}

Specimens of the new populations of $G$. cf. eremica were collected from large spring-fed pools (tinajas or oases) in the intermittently dry arroyos of 2 sub-tropical canyons, La Balandrona $(n=30)$ and La Pirinola $(n=30)$ situated in the Sierra El Aguaje (Fig. 1), during April 2000 and June 2014. Specimens were captured with small minnow-seines and preserved in $10 \%$ formalin, and later transferred to 50\% ethanol for deposition in the Native Fish Collection of the Departamento de Investigaciones Científicas y Tecnológicas of the Universidad de Sonora (DICTUS), Hermosillo, Sonora. Several species of Gila, including G. eremica, G. purpurea, G. ditaenia, and G. minacae, all collected in Sonora, Mexico (Table 1, Fig. 1), were examined in the same fish collection. The morphometric and meristic analyses also included 30 specimens of $G$. eremica designated as 


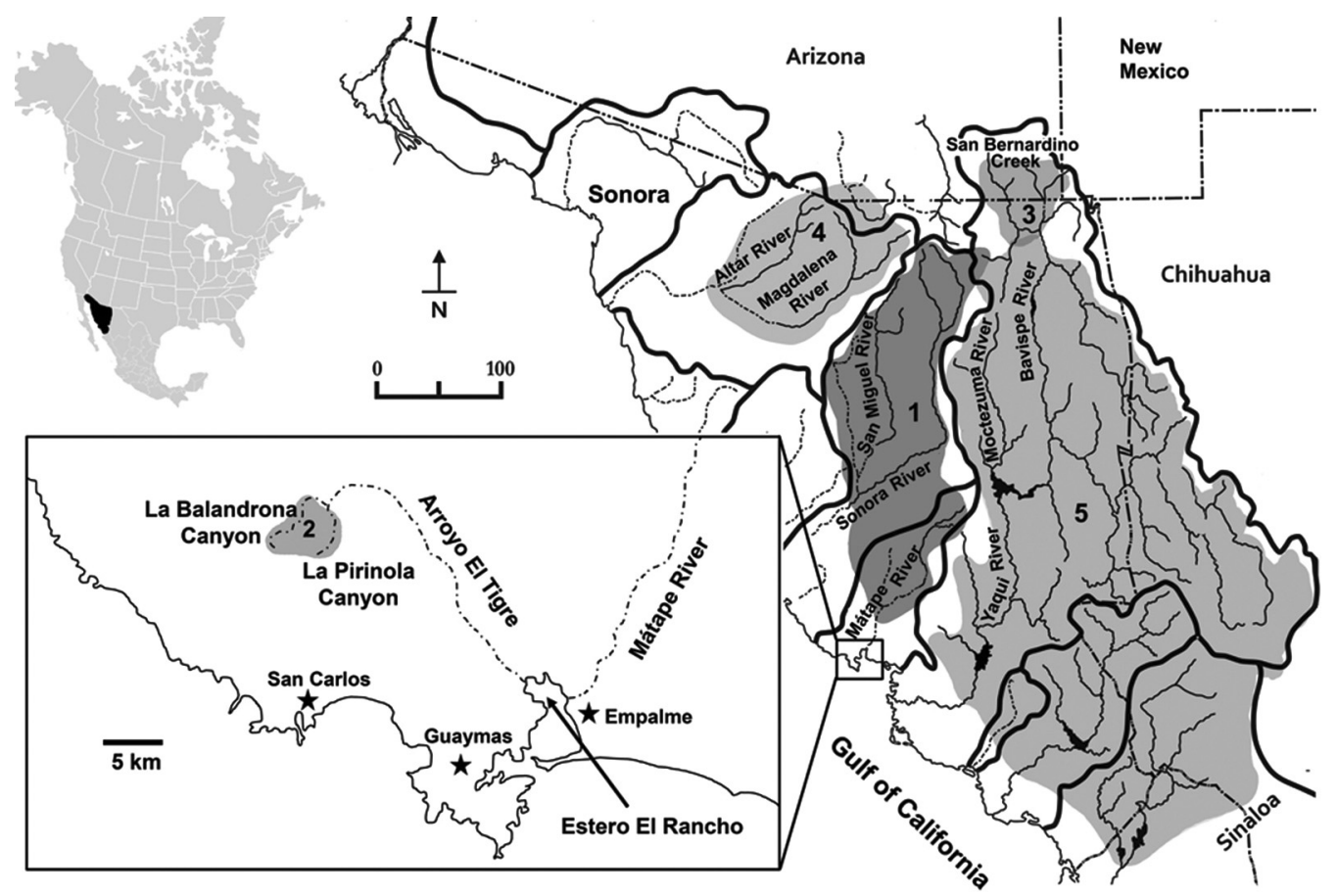

Figure 1. Major drainage basins of Sonora and distribution of Gila species used in the morphometric analysis. (1) Gila eremica, (2) Gila cf. eremica, (3) Gila purpurea, (4) Gila ditaenia, and (5) Gila minacae (see Table 1 for specimen localities). Hydrographic divides are indicated by thick lines. Dashed lines indicate intermittent drainage courses.

Table 1

Materials examined of the genus Gila, including paratypes designated by DeMarais (1991). USON=Universidad de Sonora $($ Hermosillo); ASU = Arizona State University (Tempe).

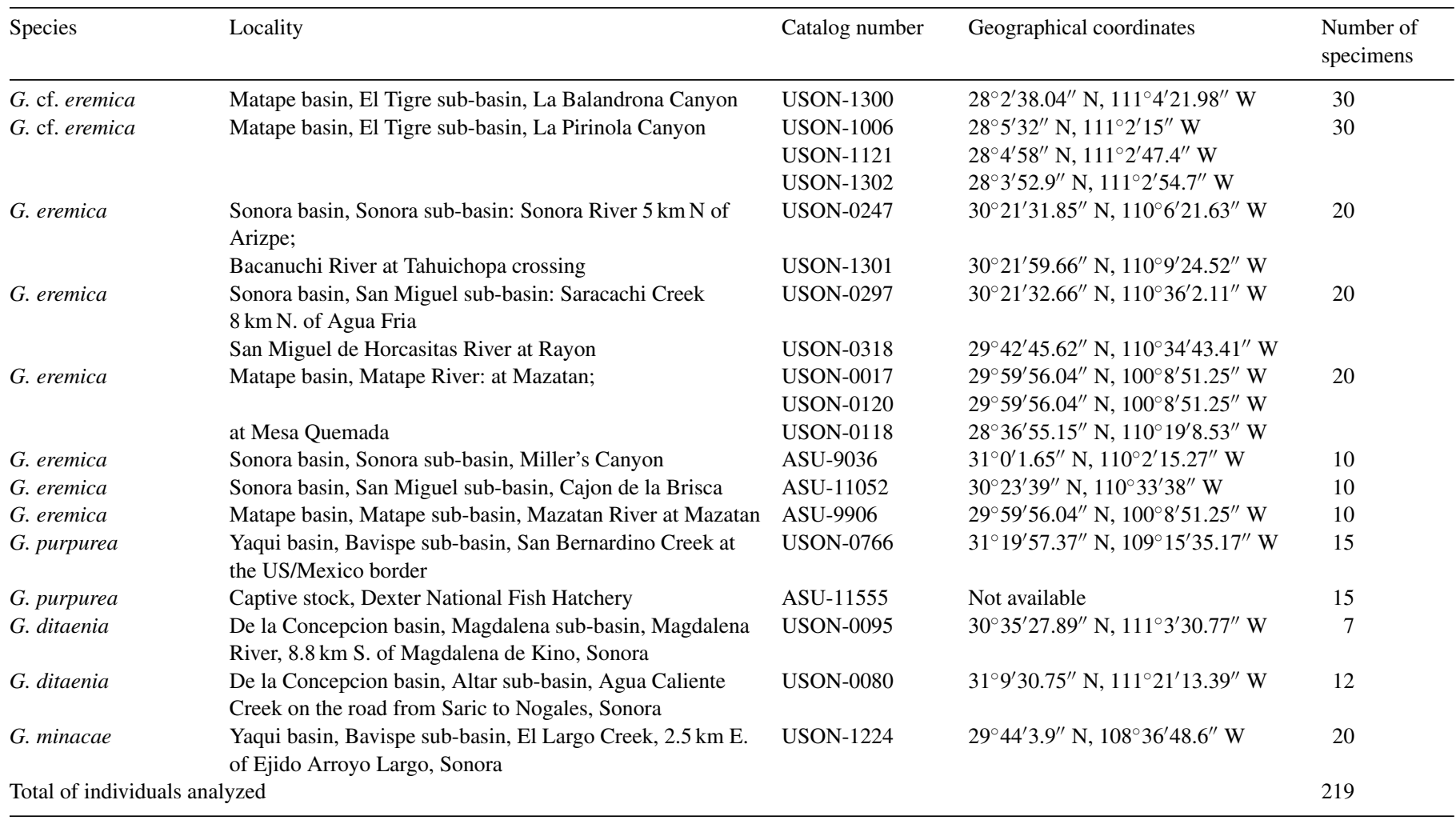




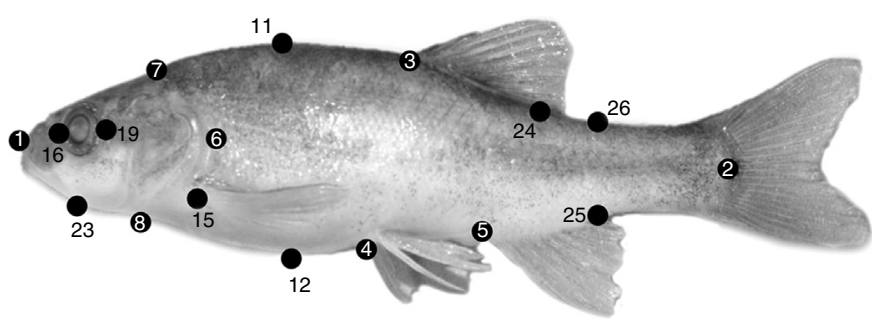

Figure 2. Landmarks for box-truss protocol used in specimens of Gila analyzed See Table 2 for explanation of codes. Specimen pictured is Gila cf. eremica (photo Gorgonio Ruiz-Campos).

paratypes by DeMarais (1991) and 15 specimens of G. purpurea deposited in the Fish Collection of the Arizona State University, Tempe, Arizona (Table 1).

Thirty-three morphometric and 6 meristic characters for the analyses were used to examine 219 adult specimens. Morphometry was based on the box-truss protocol (Bookstein et al., 1985) and meristics on Hubbs and Lagler (1958). Each specimen examined was measured using a digital caliper (precision $0.01 \mathrm{~mm}$ ) connected to a computer. Morphometric and meristic characters are shown and described in Figure 2 and Table 2, respectively.

The model for the standardization of the morphometric data of the specimens examined was the regression of Elliott, Haskard, and Koslow (1995), which removes the size component from the shape measurements (allometry) and homogenizes their variances (Jolicoeur, 1963). The regression of Elliott was calculated for each character by the equation:

$$
M_{s}=M_{o}\left(\frac{L_{s}}{L_{t}}\right)^{b}
$$

where $M_{S}=$ standardized measurement of the character, $M_{o}=$ original measurement of the character $(\mathrm{mm}), L_{S}=$ average standard length $(\mathrm{mm})$ of all specimens from all taxa examined, $L_{t}=$ standard length $(\mathrm{mm})$ of specimen, and " $b$ " was estimated for each character from the observed data by the non-linear regression equation, $M=a L^{b}$. Parameter " $b$ " was estimated as the slope of the regression $\log M_{o}$ on $\log L_{t}$ using all fish.

Standardized morphometric and meristic values for the 219 specimens were analyzed among populations of sub-basins by means of "forward stepwise discriminant" function analysis (DFA) using Statistica 5.0 (StatSoft, Inc., Tulsa), in order to determine which combinations of variables discriminated best among the analyzed groups.

\section{Results}

The DFA applied to 219 specimens of Gila from 9 subbasins in Sonora, selected 36 of the 39 morphologic characters analyzed (Table 3 ). Overall value of Wilks lambda $(\lambda)$ was $0.00001(p<0.0000)$, indicating great significant discrimination between groups. The 16 most significant variables $(p<0.001)$ obtained were: eye diameter $(\lambda=0.000007)$, caudal peduncle depth $(\lambda=0.000007)$, head length $(\lambda=0.000007)$, fleshy interorbital width $(\lambda=0.000007)$, postorbital length $(\lambda=0.000007)$, upper jaw length $(\lambda=0.000007)$, dorsal fin origin to anal fin origin $(\lambda=0.000007)$, gill raker number
Table 2

Linear measures (distances) based on box-truss protocol and meristic characters quantified for populations of the genus Gila in Sonora, Mexico (see Figure 2 for landmarks)

\begin{tabular}{ll}
\hline Code & Morphometric character \\
\hline M1-2 & Standard length \\
M1-3 & Predorsal length \\
M1-4 & Prepelvic length \\
M2-5 & Anal-fin origin to hypural plate \\
M1-6 & Head length \\
M1-7 & Mid-dorsal head length \\
M7-8 & Head depth \\
M9-10 & Head width \\
M11-12 & Body depth \\
M13-14 & Body width \\
M4-15 & Pectoral-fin origin to pelvic-fin origin \\
M-16 & Snout length \\
M-17 & Snout to isthmus length \\
M-18 & Chin to isthmus length \\
M-19 & Eye diameter \\
M-20 & Postorbital length \\
M-21 & Fleshy interorbital width \\
M-22 & Upper jaw length \\
M-23 & Mouth width \\
M5-24 & Caudal peduncle length \\
M25-26 & Caudal peduncle depth \\
M-27 & Pelvic-fin length \\
M-28 & Dorsal-fin length \\
M-29 & Anal-fin length \\
M-30 & Pectoral-fin length \\
M-31 & Caudal-fin length \\
M3-15 & Dorsal-fin origin to pectoral-fin \\
M3-4 & origin \\
M3-5 & Dorsal-fin origin to pelvic-fin origin \\
M3-25 & Dorsal-fin origin to anal-fin origin \\
M3-2 & Dorsal-fin origin to base of last \\
M4-5 & anal-fin ray \\
M15-19 & Dorsal-fin origin to hypural plate \\
Meristic character & Pelvic-fin origin to anal-fin origin \\
(1) Gill-raker number & Pectoral-fin origin to posterior \\
(2) Dorsal-fin rays & margin of orbit \\
(3) Anal-fin rays & \\
(4) Pectoral-fin rays & \\
(6) Lateral-line scales & \\
\hline & \\
\hline
\end{tabular}

$(\lambda=0.000007)$, dorsal fin length $(\lambda=0.000007)$, pectoral fin length $(\lambda=0.000007)$ and pelvic fin length $(\lambda=0.000007)$, dorsal fin rays $(\lambda=0.000007)$, left pelvic fin rays $(\lambda=0.000008)$, body width $(\lambda=0.000009)$, lateral line scales $(\lambda=0.000011)$, pectoral fin rays $(\lambda=0.000013)$ (Table 3$)$.

Standardized coefficients of canonical variables (roots) 1 and 2 obtained from the DFA explained $51.67 \%$ and $72.36 \%$ of the variation among the populations analyzed, with 9 principal variables for discriminate groups (Table 4). In canonical root 1 , the variables with major effects were: lateral line scales $(Y=0.76974)$, eye diameter $(Y=0.47073)$, left pelvic fin rays $(Y=0.44503)$, and fleshy interorbital width $(Y=-0.30356)$. For root 2, variables with major effects were: pectoral fin rays $(Y=0.769969)$, caudal peduncle length $(Y=0.404508)$, 
Table 3

Lambda values of Wilks significance $(p)$ and tolerance for 36 variables selected by forward stepwise discriminant function analysis for genus Gila in Northwest Mexico.

Discriminant function analysis summary. Step $36, n$ of vars. in model: 36 .

Wilks and apos. Lambda: 0.00001 approx. $F(396,1847)=10.085, p<0.0000$

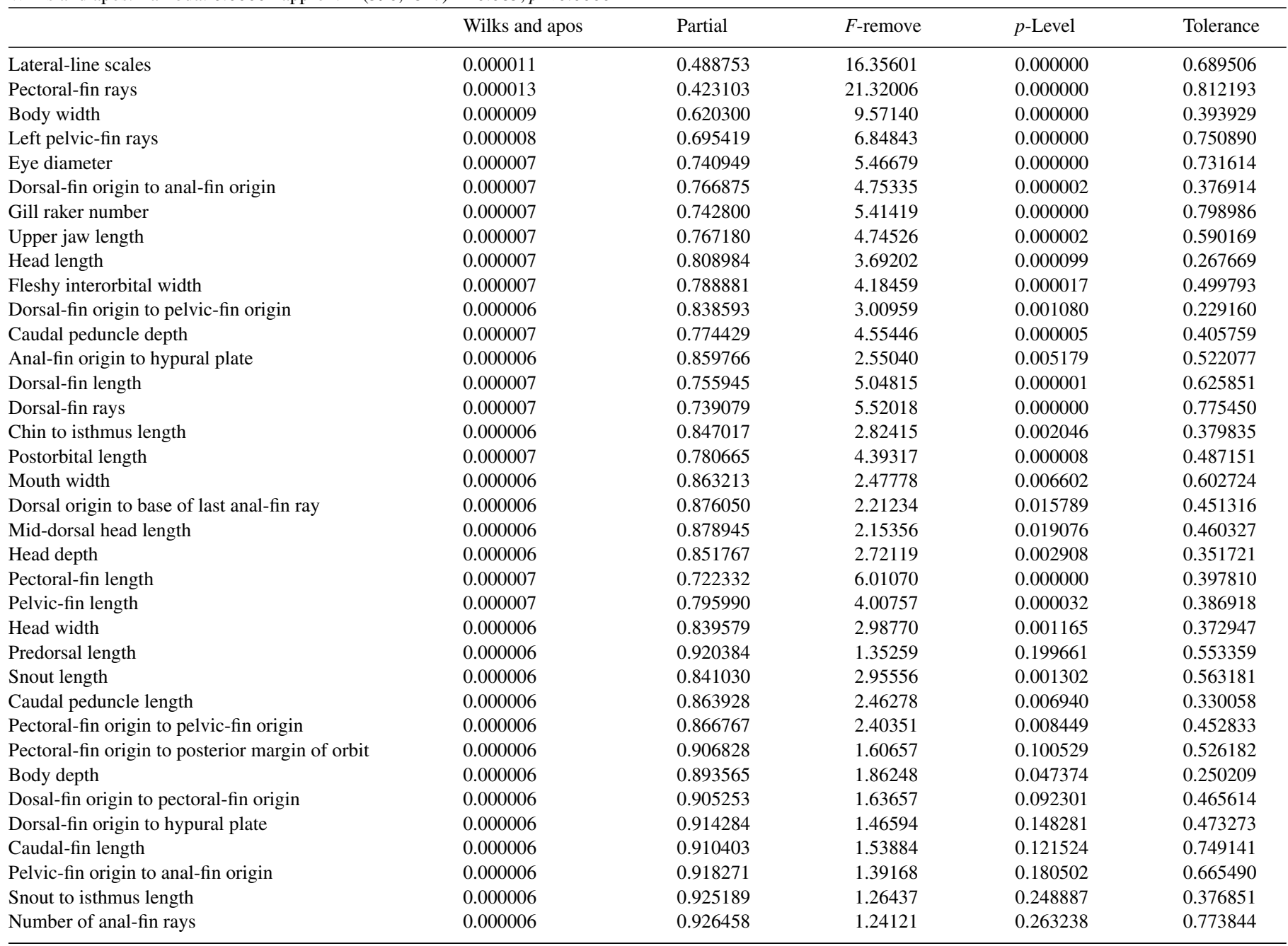

dorsal fin length $(Y=-0.355048)$, chin to isthmus length $(Y=-0.325370)$, and pelvic fin length $(Y=0.309796)$. Predictive classification of individuals for all groups showed an overall value of $97.7 \%$. Populations of G. eremica from the Sonora River sub-basin (90\%) shared 2 individuals with the San Miguel de Horcasitas River sub-basin population (100\%), and the populations of G. cf. eremica from La Pirinola Canyon (96.6\%) shared 1 individual with La Balandrona Canyon (100\%).

The tree diagram resulting from the squared Mahalanobis distances $\left(D^{2}\right)$, which indicate the extent of discrimination among populations, revealed a degree of discrimination among populations (Fig. 3). Five groups were formed at a level of cutting of 60\%: (1) all G. eremica populations from the Sonora, San Miguel de Horcasitas, and Matape rivers sub-basins, including the examined paratypes, (2) G. purpurea population from San Bernardino Creek, (3) G. cf. eremica populations from La Balandrona - La Pirinola canyons, (4) G. ditaenia populations from Magdalena and Altar rivers, and (5) G. minacae population from Bavispe River. Both populations of $G$. cf. eremica were notably discriminated from those of G. eremica and G. purpurea. Also, $G$. cf. eremica was morphologically discriminated from G. ditaenia populations (Magdalena and Altar rivers). Finally, G. minacae (Bavispe River) was the most distant morphologically population of the Gila within the populations analyzed (Fig. 3).

The resulting scatterplot of the categorization on the basis of the canonical roots 1 and 2 for the 12 populations examined of Gila, located individuals from each population with their corresponding species (Fig. 4). Specimens of G. eremica from the Sonora, San Miguel de Horcasitas, and Matape rivers subbasins, and the paratypes examined, all of them appear as a group in the scatterplot. Also, G. eremica group was located in juxtaposition with $G$. purpurea of the Bavispe River subbasin, suggesting a close morphological relation among them. Both $G$. ditaenia populations from Magdalena and Altar River sub-basins appear as a single group, isolated from the rest of populations analyzed, and $G$. minacae from Bavispe River sub-basin, the most distant morphologically population of all 
Unweighted pair-group average

Chebychev distance metric

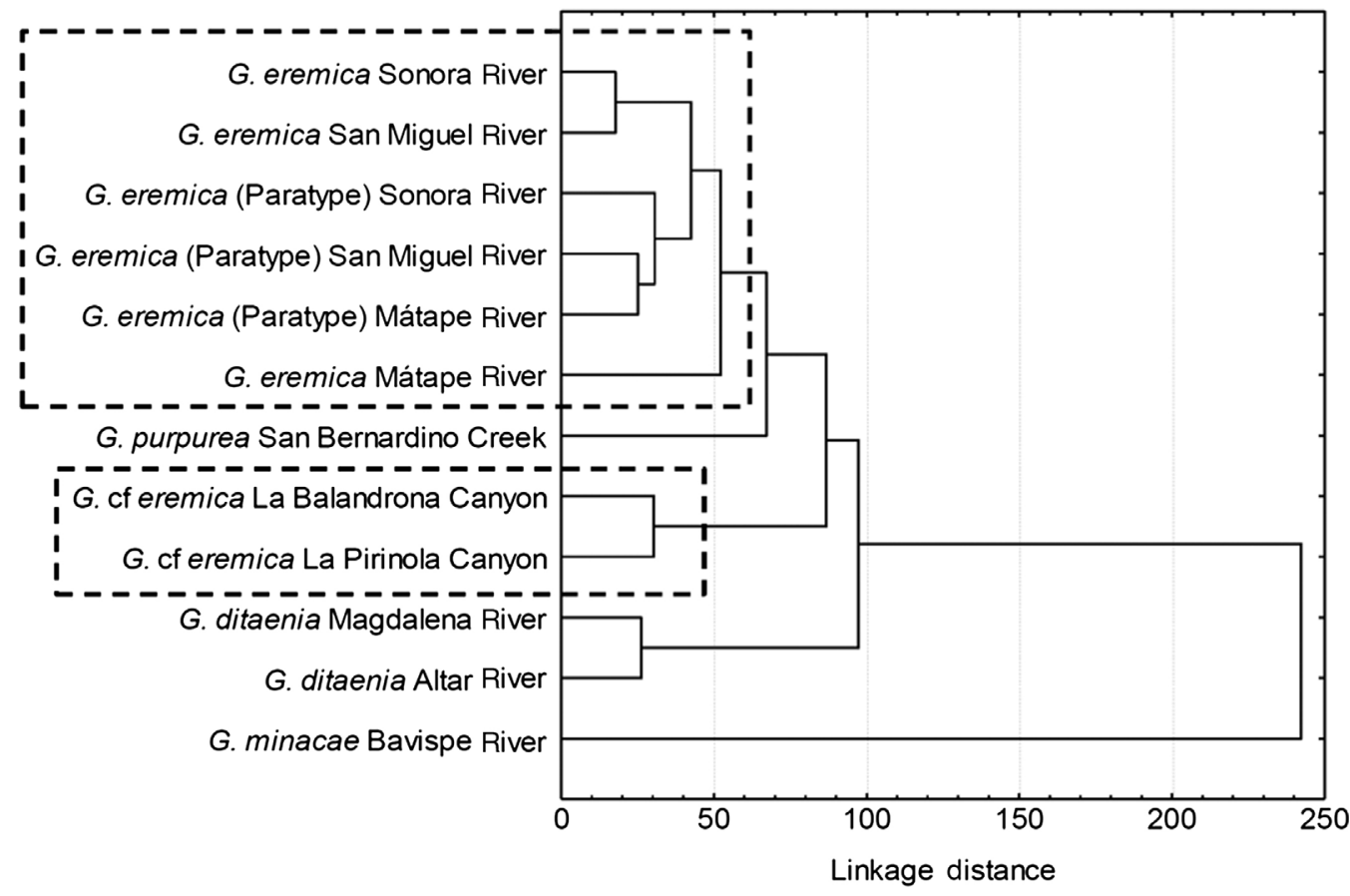

Figure 3. Tree diagram resulting from squared Mahalanobis distances for populations of Gila in Northwest Mexico.

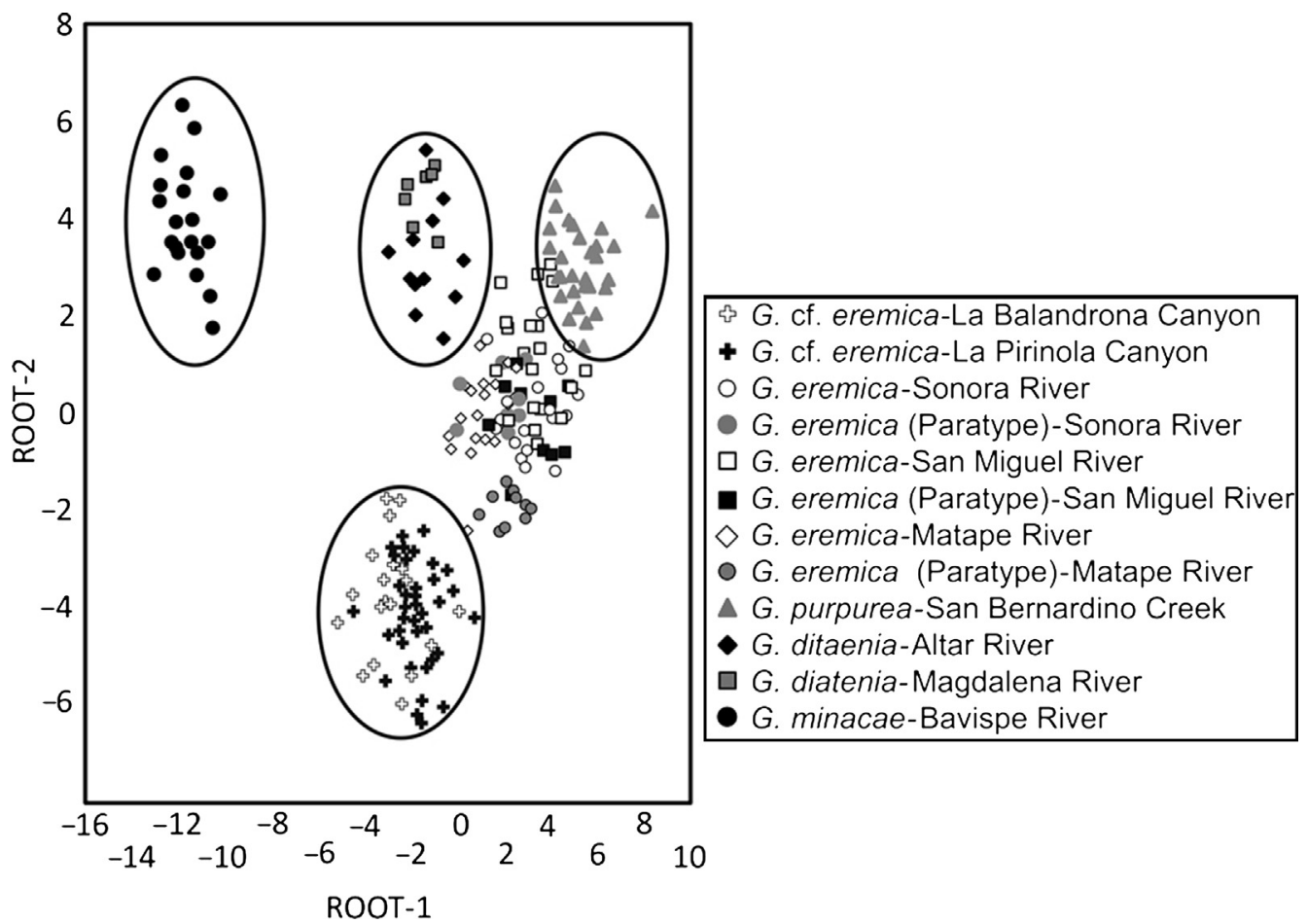

Figure 4. Scatterplots of centroids of specimens of Gila from northwestern Mexico (see Table 2 for standardized coefficients of canonical variables).

the examined species. Specimens of G. cf. eremica from La Balandrona and La Pirinola populations were morphologically related each other and are isolated from those of $G$. eremica and other species of the genus Gila analyzed here (Fig. 4).
Box plots explain the character variation around the mean of 16 linear and 2 meristic characters, and contribute to distinguish G. cf. eremica from other populations of G. eremica (Sonora, San Miguel de Horcasitas, and Matape rivers sub-basins; Fig. 5). Linear characters depicted in box plots show that $G$. cf. eremica 

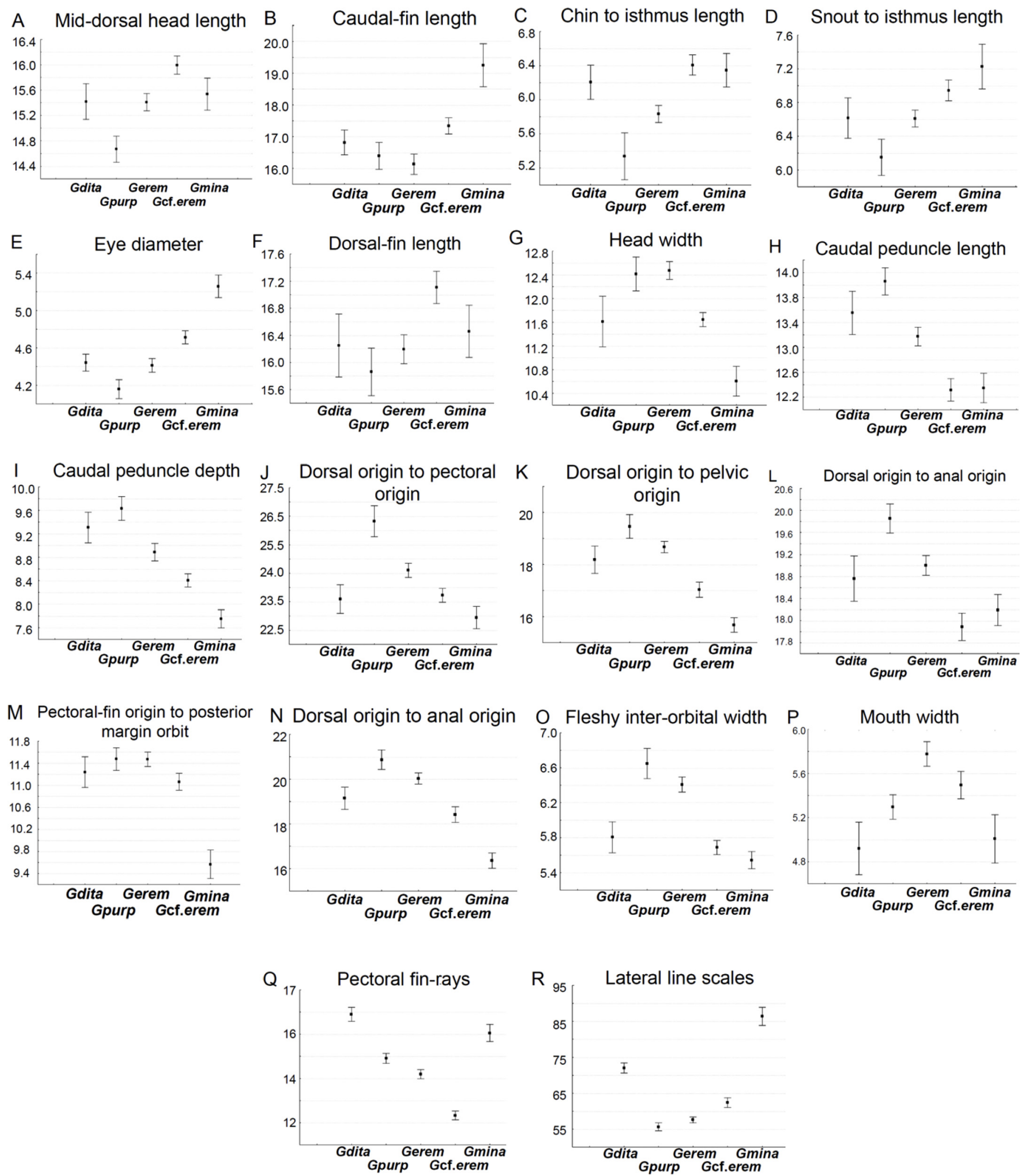

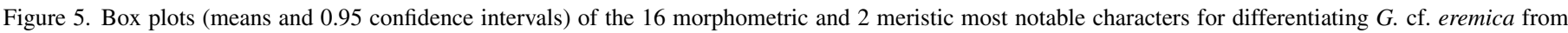

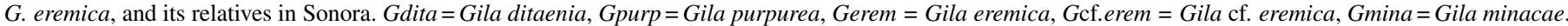


Table 4

Standardized coefficients of canonical variables resulting from the forward stepwise DFA for meristic and standardized morphometric data for populations of Gila in Northwest Mexico.

\begin{tabular}{|c|c|c|}
\hline Variable & Root 1 & Root 2 \\
\hline Lateral-line scales & 0.76974 & 0.223118 \\
\hline Pectoral-fin rays & -0.11876 & 0.769969 \\
\hline Body width & 0.21254 & -0.081903 \\
\hline Left pelvic-fin rays & 0.44503 & 0.251517 \\
\hline Eye diameter & 0.47073 & -0.093308 \\
\hline Dorsal-fin origin to anal-fin origin & -0.16995 & 0.292728 \\
\hline Gill raker number & 0.26933 & -0.095938 \\
\hline Upper jaw length & 0.08110 & -0.112509 \\
\hline Head length & -0.10649 & -0.137349 \\
\hline Fleshy interorbital width & -0.30356 & 0.225682 \\
\hline Dorsal-fin origin to pelvic-fin origin & -0.06771 & -0.043964 \\
\hline Caudal peduncle depth & -0.09354 & 0.118636 \\
\hline Anal-fin origin to hypural plate & 0.09056 & -0.226180 \\
\hline Dorsal-fin length & 0.33916 & -0.355048 \\
\hline Dorsal-fin rays & 0.09270 & 0.238970 \\
\hline Chin to isthmus length & 0.19597 & -0.325370 \\
\hline Postorbital length & -0.08409 & 0.172674 \\
\hline Mouth width & -0.05710 & 0.059838 \\
\hline Dorsal origin to base of last anal-fin ray & -0.09337 & -0.227314 \\
\hline Mid-dorsal head length & 0.29850 & -0.279097 \\
\hline Head depth & -0.18544 & -0.105579 \\
\hline Pectoral-fin length & -0.04293 & -0.057245 \\
\hline Pelvic-fin length & 0.00245 & 0.309796 \\
\hline Head width & -0.05100 & 0.023703 \\
\hline Predorsal length & 0.15031 & 0.025810 \\
\hline Snout length & 0.16754 & 0.095840 \\
\hline Caudal peduncle length & 0.04583 & 0.404508 \\
\hline Pectoral-fin origin to pelvic-fin origin & 0.04220 & -0.070744 \\
\hline $\begin{array}{l}\text { Pectoral-fin origin to posterior margin } \\
\text { of orbit }\end{array}$ & -0.12483 & 0.063458 \\
\hline Body depth & -0.22292 & -0.112075 \\
\hline Dosal-fin origin to pectoral-fin origin & -0.17920 & -0.196471 \\
\hline Dorsal-fin origin to hypural plate & 0.15664 & -0.088975 \\
\hline Caudal-fin length & 0.21167 & -0.008323 \\
\hline Pelvic-fin origin to anal-fin origin & 0.06608 & 0.000897 \\
\hline Snout to isthmus length & 0.08791 & -0.169208 \\
\hline Anal-fin rays & -0.23251 & -0.008403 \\
\hline Eigenvalue & 22.21117 & 8.891306 \\
\hline Cum.Prop & 0.51675 & 0.723607 \\
\hline
\end{tabular}

has several characters longer compared with those of nominal species G. eremica: mid-dorsal head length, caudal fin length, chin to isthmus length, snout to isthmus length, eye diameter, dorsal fin length (Fig. 5A-F); likewise some smaller characters such as head width, caudal peduncle length, caudal peduncle depth, dorsal origin to pectoral origin, dorsal origin to pelvic origin, dorsal origin to anal origin, pectoral origin to orbit, body depth, fleshy inter-orbital width, and mouth width (Fig. 5G-P). Gila cf. eremica has a slimmer body compared with that of $G$. eremica. Meristic characters in box plots for $G$. cf. eremica indicated a smaller number of pectoral fin rays and a higher number of lateral line scales compared with G. eremica (Fig. 5Q and R).

\section{Discussion}

The taxonomically heterogeneous and widespread genus Gila includes the Sonora occurring species of the Revised
Western Clade inhabiting drainage systems in the Western USA and Northwest Mexico (Schönhuth et al., 2012). Within the RWC, Schönhuth et al. (2014) identified 3 major areas of diversification/patterns of endemism in river basins and delineated phylogenetic relationships within the Gila lineage, one being in the Pacific drainages of Northwest Mexico. Schönhuth et al. (2014) postulated that within this southern lineage, Gila species in Sonora were reciprocally monophyletic, and that $G$. purpurea was closest to G. eremica, where the first probably derived from the latter (Schönhuth et al., 2014).

Inferred phylogenetic relationships and distributions of the major southern lineages of Gila performed by Schönhuth et al. (2014) provide evidence that southern lineages follow a pattern of endemism in each major river basin, wherein a single species inhabit a particular drainage. In addition, that study provides substance, that the distributional patterns of Gila species in Mexico involves vicariance (model I speciation) (Wiley, 1981), where taxa are replaced in different drainages with those of the same species or closely related (sister) species; as well as other distributions and phylogenetic relationships among Gila being consistent with a model that involves divergences of populations from small geographic areas (model III speciation) (Mayden, 1999, 2002). Schönhuth et al. (2014) suggest that the sister group relationship of the G. eremica (Sonora and Matape rivers) and G. purpurea (Bavispe River of the northern Yaqui system) may be explained by the peripheral isolation mode of speciation. The morphologic and meristic differences detected in our study of G. cf. eremica populations of La Balandrona and La Pirinola canyons of the Arroyo El Tigre drainage, may be explained as an evolutionary radiation within the G. eremica lineage. We also think it plausible that the formation of the emplacement of the volcanic Sierra Santa Ursula mountain range (ca. 23 to 8 millions of years ago, Mora-Álvarez \& McDowell, 2000), just eastward of the Arroyo El Tigre drainage, caused the disconnection of that drainage from main course of the Matape River, subsequently followed by the progressive drying of water courses in this region of the Sonoran Desert, as major factor in isolating formerly connected populations of fishes such as G. eremica and $G$. cf. eremica and leading to their divergences in morphology, similar to what has been suggested for the G. purpurea population occupying San Bernardino Creek of the Bavispe River sub-basin of the Yaqui system (Schönhuth et al., 2014).

Our analyses propose that at least16 linear and 2 meristic characters allow to differentiate $G$. cf. eremica from other G. eremica populations. Larger somatic features were associated to eye diameter, mid-dorsal head length, chin and snout to isthmus lengths, dorsal and caudal fin lengths; while those smallest were associated to head width, fleshy inter-orbital width, pectoral-fin origin to posterior margin of orbit, caudal peduncle length and depth, dorsal fin origin to pectoral fin origin, pelvic fin, and anal fin origins. In addition, 2 meristic characters in box plots were recognized here as diagnostic characters: lateral line scales and number of pectoral fin rays. Gila cf. eremica presently is known only from the Arroyo El Tigre sub-basin, which now is an independent drainage of the Matape River basin.

The morphologic and meristic differences detected in the DFA among the 2 populations of $G$. cf. eremica compared with 
their congeners in Sonora, provides the first recognition of the isolated chub populations in the low elevation canyons, and calls for the development of molecular analyses to further clarify the evolutionary affinities of the endemic $G$. cf. eremica with other related taxa in Sonora.

\section{Acknowledgements}

To Richard Felger and Jesús Sánchez-Escalante for noticing the presence of fish in pools during his plant collections in the canyons. We also thank Michael T. Bogan, Nohemí Noriega-Félix, Sylvette Leonor Vidal-Aguilar, Celso Haros-Méndez, Emmanuel Mario Bernal-Loaiza, and Dylann Córdova-Martínez for fish collection. Thomas Dowling and Charlotte Johnston for providing paratypes of G. eremica and G. purpurea from the Arizona State University Fish Collection. Field collections were made under Mexican government permits DGOPA.03947.250406.1606 and SGPA/DGVS/00505/10. Karen L. Ballesteros-Córdova designed Figure 1. The first author is receiving a fellowship from Conacyt for doctoral studies. This work was funded by Conacyt.

\section{References}

Barbour, C. D., \& Miller, R. R. (1978). A revision of the Mexican cyprinid fish genus Algansea. Miscellaneous Publications, Museum of Zoology University of Michigan, 155.

Bookstein, F. L., Chernoff, B., Elder, R. L., Humphries, J. M., Smith, G. R., Jr., \& Strauss, R. E. (1985). Morphometrics in evolutionary biology. Philadelphia, PA: Academy of Natural Sciences.

Branson, B. A., McCoy, C. J., \& Sisk, M. E. (1960). Notes on the freshwater fishes of Sonora with an addition to the known fauna. Copeia, 3, 217-220.

Bufalino, A. P., \& Mayden, R. L. (2010a). Phylogenetic relationships of North American phoxinins (Actinopterygii: Cypriniformes: Leuciscidae) as inferred from S7 nuclear DNA sequences. Molecular Phylogenetics and Evolution, 5, 143-152.

Bufalino, A. P., \& Mayden, R. L. (2010b). Molecular phylogenetics of North American phoxinins (Actinopterygii: Leuciscidae) based on RAG1 and S7 nuclear DNA sequence data. Molecular Phylogenetics and Evolution, 55, 274-283.

Bufalino, A. P., \& Mayden, R. L. (2010c). Phylogenetic evaluation of North American Leuciscidae (Actinopterygii: Cypriniformes: Cyprinoidea) as inferred from analyses of mitochondrial and nuclear DNA sequences. Systematics and Biodiversity, 8, 493-505.

DeMarais, B. D. (1991). Gila eremica, a new cyprinid fish from northwestern Sonora, México. Copeia, 1, 179-189.

DeMarais, B. D., Dowling, T. E., Douglas, M. E., Minckley, W. L., \& Marsh, P. C. (1992). Origin of Gila seminuda (Teleostei: Cyprinidae) through introgressive hybridization: implications for evolution and conservation. Proceedings of the National Academy of Sciences of the United States of America, 89, 2747-2751.

Dowling, T. E., \& DeMarais, B. D. (1993). Evolutionary significance of introgressive hybridization in cyprinid fishes. Nature, 362, 444-446.

Elliott, N. G., Haskard, K., \& Koslow, J. A. (1995). Morphometric analysis of orange roughy (Hoplostethus atlanticus) off the continental slope of southern Australia. Journal of Fish Biology, 46, 202-220.

Gerber, A. S., Tibbets, C. A., \& Dowling, T. E. (2001). The role of introgressive hybridization in the evolution of the Gila robusta complex (Teleostei: Cyprinidae). Evolution, 55, 2028-2039.

Hendrickson, D. A., Miller, W. L., Siebert, D. J., \& Minckley, P. H. (1981) Fishes of the Río Yaqui, basin México and United States. Journal of the Arizona-Nevada Academy of Science, 15, 65-106.

Hubbs, C. L., \& Lagler, K. F. (1958). Fishes of the Great Lakes region. Ann Arbor, MI: University of Michigan Press.

Jolicoeur, P. (1963). The multivariate generalization of the allometry equation. Biometrics, 19, 497-499.

Mayden, R. L. (1999). Consilience and a hierarchy of species concepts: advances towards closure on the species puzzle. Journal of Nematology, 31, 95-116.

Mayden, R. L. (2002). On biological species, species concepts, and individuation in the natural world. Fish and Fisheries, 2, 1-26.

Miller, R. R. (1959). Origin and affinities of the fresh-water fish fauna of western North America. In C. L. Hubbs (Ed.), Zoogeography (pp. 187-222) Washington, DC: Publication of the Association of Advances in Science.

Miller, R. R., Minckley, W. L., \& Norris, S. (2005). Freshwater fishes of Mexico. Chicago, IL: University of Chicago Press.

Mora-Álvarez, G., \& McDowell, F. W. (2000). Miocene volcanism during late subduction and early rifting in the Sierra Santa Úrsula of western Sonora, México. In H. Delgado-Granados, G. Aguirre-Díaz, \& J. M. Stock (Eds.), Cenozoic tectonics and volcanism of Mexico: Boulder, Colorado (pp. 123-141). Geological Society of America Special Paper.

Schönhuth, S., Perdicles, A., Lozano-Villano, L., García-de-León, F. J., Espinosa, H., \& Mayden, R. L. (2014). Phylogenetic relationships of North American western chubs of the genus Gila (Cyprinidae, Teleostei), with emphasis on southern species. Molecular Phylogenetics and Evolution, 70 210-230.

Schönhuth, S., Shiozawa, D. K., Dowling, T. E., \& Mayden, R. L. (2012). Molecular systematics of western North American cyprinids (Cypriniformes: Cyprinidae). Zootaxa, 3586, 281-303.

Simons, A. M., Berendzen, P. B., \& Mayden, R. L. (2003). Molecular systematics of North American phoxinin genera (Actinopterygii: Cyprinidae) inferred from mitochondrial $12 \mathrm{~S}$ and $16 \mathrm{~S}$ ribosomal RNA sequences. Zoological Journal of the Linnean Society, 139, 63-80.

Simons, A. M., \& Mayden, R. L. (1997). Phylogenetic relationships of the Creek Chubs and the Spine-Fins: an enigmatic group of North American cyprinid fishes (Actinopterygii: Cyprinidae). Cladistics, 13, 187-205.

Varela-Romero, A. (2001). Newly documented localities for desert chub, Gila eremica, in tropical canyons, Río Mátape Basin, Sonora, México. Proceedings of the Desert Fishes Council, 33, 1068-1381.

Wiley, E. O. (1981). Phylogenetics. The theory and practice of phylogenetic systematics. New York: Wiley-Interscience. 